\title{
POTĘGA CZY NIEMOC WIZERUNKU1? W STRONĘ SEMIOTYCZNEJ ANALIZY PRZEDSTAWIEŃ EDYTY STEIN W CYBERPRZESTRZENI
}

Czy można mówić o cyfrowym przedstawieniu świętego? Czy można analizować jego obecność w cyberprzestrzeni? Wreszcie czy możliwym jest badanie jego internetowego wizerunku? Na tak postawione pytania paść mogą rozliczne odpowiedzi, motywowane głównie wyjściową pozycją teoretyczną odpowiadającego. Celem tego szkicu jest nakreślenie wybranych ustaleń semiotyki w zakresie badania wizualności, $\mathrm{w}$ tym także obrazów cyfrowych, oraz zaaplikowanie tychże ustaleń do kilku przedstawień Edyty Stein zamieszczonych w Internecie. Przedstawiając cel, udzieliłam więc już z góry twierdzącej odpowiedzi na wskazane pytania.

\section{Rozstrzygnięcia pojęciowe: znak ikoniczny - przedstawienie - obraz}

Rozpocznę od koniecznych pojęciowych rozstrzygnięć, których należy dokonać dla precyzji wywodu. Wszystkie wspomniane tu terminy i pojęcia należą do szeroko rozumianej semiotyki wizualności i analizy iko-

${ }^{1}$ Brzmienie pierwszej części tytułu jest parafrazą tytułu książki Davida Freedberga Potęga wizerunków. Studia z historii i teorii oddziaływania, tłum. E. Klekot, Kraków 2005. 
nograficznej, a prezentowane są tu - z konieczności - jedynie na zasadzie krótkiego przeglądu. Reprezentację rozumiem jako zjawisko o charakterze znakowym, będące przedstawieniem danego obiektu lub jego uobecnieniem, co odnosi się zwłaszcza do symbolu, w którym reprezentacja jest tożsama ze swym przedmiotem. Reprezentacja znakowa $w$ literaturze przedmiotu bywa rozumiana na wiele sposobów, raz wiąże się ją z referencją, raz z denotacją, innym znów razem z przedstawieniem. Samo semiotyczne jej ujęcie nie jest jednoznaczne i semiotycy stosują je w wielu znaczeniach. Reprezentacja wizualna, a więc ta, która szczególnie mnie interesuje, jest obrazem, rozumianym jako struktura znakowa. Ujęta w perspektywie semiotycznej, pozwala analizować wizualne fenomeny poprzez odniesienie do takich pojęć, jak przedstawienie, mediacja, obraz czy szereg i w znakomitej większości przypadków: syntagma, znak ikoniczny. Nie chcąc nadmiernie rozbudowywać tych akapitów, które nie tyczą się bezpośrednio Edyty Stein, niech wolno mi będzie jedynie uzupełnić powyższy katalog pojęć o specyficznie rozumiane przedstawienie wizualne $\mathrm{w}$ optyce najnowszej ikonologii i medioznawstwa. W.J.T. Mitchell w swoim głośnym manifeście The Pictorial Turn z 1992 roku charakteryzuje zwrot obrazowy jako postlingwistyczny i postsemiotyczny nurt $\mathrm{w}$ refleksji nad obrazem² ${ }^{2}$ Proponuje badać przedstawienia wizualne zgodnie z podejściem właściwym ich określeniu - jako wizualne właśnie, a nie językowe. Rezygnacja z semiotycznych metod badania obrazu opartych na dokonaniach lingwistyki okazuje się czymś zupełnie nowatorskim i bliżej metodologicznie niedookreślonym. Jest ponadto w swej radykalności - przekreśleniem zdobyczy semiotyki strukturalnej i po części - Peirce'owskiej, gdyż odchodzi zarówno od propozycji badaczy reprezentujących szkołę tartusko-moskiewską, jak i podważa głośne „retoryki obrazu" Rolanda Barthesa i Umberta Eco. W swojej późniejszej pracy Czego chca obrazy? Mitchell nie jest już tak radykalny, więcej nawet, powołuje się na ustalenia Peirce'a i zauważa, że jego animalistyczna i witalistyczna perspektywa nie oznacza równoczesnej rezygnacji z metod semiotycznej analizy obrazu, inaczej tylko rozkłada akcenty. „Pytanie o pragnienia przedstawień wizualnych z pewnością nie wyklucza interpretacji znaków. Dokonuje ono jednak subtelnego przesunięcia celu interpretacji, niewielkiego przeobrażenia naszego obrazu samych przedstawień (a może i znaków)"3. Możliwie syntetyzując podejście Mitchella, powiedzieć można, że obraz rozumie on jako fenomen wirtualny, fantazmatyczny, przedstawienie zaś jako obraz wraz z jego podstawą: materialnym medium. Wspomniane cechy

2 W.J.T. Mitchell, Zwrot piktorialny, „Kultura Popularna” 2009, nr 1(23).

${ }^{3}$ Tenże, Czego chca obrazy? Pragnienia przedstawień, życie i miłość obrazów, tłum. Ł. Zaremba, Warszawa 2013, s. 78-79. 
omawianej koncepcji - animalistyczne i witalistyczne rozumienie obrazu prowadzą do prostego, acz kontrowersyjnego stwierdzenia: obrazy żyją. Rzecz jasna, nie ma tu na myśli Mitchell życia w sensie biologicznym, lecz życia jako posiadania (bądź nie) pragnień czy żywienia rozmaitych uczuć. Ożywiony obraz, o czym warto dla porządku wspomnieć, obecny jest też w koncepcji antropologicznej Hansa Beltinga, Mitchell jednak bada problem z nieco innej perspektywy. Niech za wystarczające pozostanie nam przywołanie sposobu, w jaki autor Czego chca obrazy? rozumie przedstawienie wizualne: „Przedstawienia są rzeczami naznaczonymi wszelkimi znamionami osobowości i ożywienia [...]. Prezentują nie tylko powierzchnię, lecz także oblicze, wobec którego stanąć musi widz"4. Jesteśmy już blisko przedstawień świętych, których oblicze jest dla widza dostępne w wirtualnej cyberprzestrzeni.

Spójrzmy na przedmiotowe zagadnienie ze zgoła innej strony. Kierunek umownie wyznaczający przemiany zjawiska reprezentacji w kulturze można - za Anną Grzegorczyk - zwięźle wyrazić na linii symbol - znak - simulacrum $^{5}$. Ostatni etap tej drogi został szczególnie rozwinięty przez myślicieli poststrukturalistycznych, takich jak na przykład Jean Baudrillard, który pisał wręcz o „precesji symulakrów”, „śmierci rzeczywistości” i „kresie realności" ${ }^{\prime}$. Koncepcję swoistego odrywania się języka od rzeczywistości oraz deregulacji referencji Baudrillard określił mianem „boskiej irreeferencji obrazu", a jej kolejne stadia zamknął w czterech etapach: (1) początkowo obraz jest odzwierciedleniem głębokiej rzeczywistości, (2) następnie obraz skrywa i wypacza tę rzeczywistość, (3) kolejnym etapem jest skrywanie przez obraz nieobecności głębokiej rzeczywistości, i wreszcie (4) obraz nie pozostaje już w żadnym związku z rzeczywistością; tutaj wkracza się w epokę simulacrum - znaków bez pierwowzoru, bez początku, bez odniesienia.

W ten sposób dochodzimy do problemu obrazu zdigitalizowanego, który przecież jest jedynym obrazem, jaki znaleźć można w Internecie. I znów, mamy cały szereg koncepcji - $\mathrm{w}$ tym stricte semiotycznych - obrazu cyfrowego, raz to koncentrujących się na samej jego morfologii (ciągłość - skokowość, rejestr analogowy - rejestr cyfrowy, niedyskretność - dyskretność, etc. $)^{7}$, innym razem akcentujących sposób funkcjonowania tego obrazu (mul-

4 Tamże, s. 67.

${ }^{5}$ A. Grzegorczyk, Wymykanie się symbolom, w: Kultura jako przedmiot badań, red. B. Kotowa, J. Sójka, K. Zamiara, Poznań 2001, s. 237.

${ }^{6}$ Określenia te, charakterystyczne dla dyskursu naukowego tego autora, traktować należy jako metafory epistemologiczne, stąd umieszczam je w cudzysłowie.

7 Semiotycy podejmujący ten problem - zob. np.: R. Barthes, Podstawy semiologii, tłum. A. Turczyn, Kraków 2009; tenże, Retoryka obrazu, tłum. Z. Kruszyński, „Pamiętnik Literacki” 
tiplikowalność, niematerialność, niereferencjalność). Przywołać tu warto koncepcję obrazu cyfrowego u Baudrillarda, utrzymującego swoje rozważania w perspektywie semiotycznej czy semiologizującej, głoszącego kres obrazu jako materialnego nośnika iluzji i rozprzestrzenianie się obrazów zdigitalizowanych, uznanych za znak naszych czasów. Po zwrocie wizualnym, w epoce nowych mediów obraz znacząco zmienia swój status. Obrazy zdigitalizowane oraz postępująca digitalizacja kultury otwierają przed odbiorcą, nadawcą czy użytkownikiem obrazów całkiem nowe możliwości: błyskawicznego dzielenia się nimi, przesyłania, publikowania czy modyfikowania, ale przede wszystkim nieograniczonej ich multiplikacji. Trudno już wskazać oryginał, więcej nawet, rozróżnienie na kopię i oryginał przestaje być istotne. Obraz ponadto nie stanowi już materialnego przedmiotu - przejście od analogowych, niedyskretnych przedstawień do dyskretnych, cyfrowych pozbawia go fizyczności, a $\mathrm{w}$ zamian zamyka $\mathrm{w}$ systemie numerycznym, zerojedynkowym. Wszystkie te czysto teoretyczne rozstrzygnięcia okażą się uzasadnione, gdy przejdę do omówienia konkretnych wizualnych reprezentacji wizerunku Edyty Stein w Internecie.

\section{Obecność - nieobecność. Działanie wizerunku $\mathrm{w}$ przestrzeni Internetu}

„Malarstwo uobecnia nieobecnych i ożywia martwych, wspomaga pamięć i ułatwia rozpoznawanie, może budzić gniew, przyczynia się do wzrostu pobożności, przekształca wartości nieprzedstawiającej materii"8 - pisze David Freedberg w swym słynnym dziele Potęga wizerunków. Studia $z$ historii $i$ teorii oddziatywania. W odniesieniu do statusu ontologicznego dzieła sztuki i - pośrednio - do funkcji aktu konsekracji, badacz przywołuje Gadamerowskie rozróżnienie na symbole naturalne i sztuczne, z zastrzeżeniem hermeneuty, że znaczenie dzieła sztuki nie jest zależne od konsekracji: „Znaczenia nie nadaje dopiero publiczny akt poświęcenia lub odsłonięcia, dzięki któremu dzieło uzyskuje określone przeznaczenie. Bywa raczej tak, że zanim zostanie mu nadana funkcja pomnika, jest ono już wytworem o własnej funkcji znaczeniowej, jako obrazowa lub nieobrazowa reprezentacja" ${ }^{\prime}$. Rozpatrując wpływ konsekracji wizerunków na ich sprawczość, Gadamer

1985, t. LXXVI, z. 3; U. Eco, Nieobecna struktura, tłum. A. Weinsberg, P. Bravo, Warszawa 2003; tenże Teoria semiotyki, tłum. M. Czerwiński, Kraków 2009.

${ }^{8}$ D. Freedberg, dz. cyt., s. 44.

${ }^{9}$ H.-G. Gadamer, Prawda i metoda. Zarys hermeneutyki filozoficznej, tłum. B. Baran, Kraków 1993, s. 166. 
zauważa, że przed konsekracją dzieło sztuki posiada nawet istotniejszą funkcję znaczeniową niż po tym akcie.

Wszystkie wizerunki - konkluduje Freedberg - posiadają funkcję znaczeniową i znaczącą, która jest uprzednia w stosunku do ich instytucjonalizacji za pomocą konsekracji czy innego rodzaju czynności i obrzędów. Konsekracja jest jednak ważnym zagadnieniem, ponieważ tak często towarzyszy uaktywnieniu wizerunków, dzięki czemu rzuca światło na potencjalną potęgę wszystkich wizerunków. Wizerunki działają, ponieważ zostały konsekrowane, lecz równocześnie działają przed konsekrowaniem. [...] Zjawisko konsekracji ukazuje w pełni potencjał wszystkich wizerunków; uruchamia ono ten potencjał i go urzeczywistnia [kursywa oryginalna] ${ }^{10}$.

Wzbogacając rozważania nad ontologicznym statusem konsekrowanego wizerunku o przemyślenia Gadamera, należy mieć na uwadze tradycję filozoficzną, w jakiej te ostatnie powstawały. Hermeneutyczna (w znaczeniu hermeneutyki filozoficznej) optyka - w ogromnym uproszczeniu - pozwala na ujmowanie jednostkowych fenomenów w szerszym planie nieskończonego odsyłania i powracania, stąd w przytoczonych uwagach wyróżnione przez ich autora słowa „ponieważ" i „przed”. Dla pełnego obrazu przypomnijmy wyłożoną w szkicu Aktualność piękna metaforę gry odsyłania i skrywania oraz koncepcję ruchu hermeneutycznego:

Obraz „czytamy” tak, jak czyta się pismo. „Rozszyfrowujemy” obraz jak tekst. [...] Trzeba [go] budować tak, by został, by tak rzec, przeczytany słowo po słowie, a na końcu tego nieodpartego budowania połączył się w obraz, w którym obecnie jest współbrzmiące z nim znaczenie [...]. Czytanie [polega] na dokonywaniu ustawicznego ruchu hermeneutycznego, którym steruje oczekiwanie sensu całości i który z punktu widzenia jednostki spełnia się ostatecznie w realizacji sensu całości ${ }^{11}$.

„Wszystko, co symboliczne - pisze dalej Gadamer - polega na niekończącej się grze odsyłania i skrywania"12, zaś jego istotą jest „paradoksalny akt odsyłania, który to znaczenie, do którego odsyła, zarazem w sobie samym ucieleśnia, a nawet poręcza"13. Jako że rozważania nad naturą symbolu nie są przedmiotem tego szkicu, zakończmy je w tym miejscu, a ich odnotowanie uznajmy za uzupełnienie rozstrzygnięć Freedberga dotyczących aktu poświęcenia obrazów. Jeśli więc, podsumujmy, sam akt konsekracji nie jest przesądzającym o mocy wizerunku, to pozwala to, wprawdzie scep-

${ }^{10}$ D. Freedberg, dz. cyt., s. 99.

${ }^{11}$ H.-G. Gadamer, Aktualność piękna. Sztuka jako gra, symbol i święto, tłum. K. Krzemieniowa, Warszawa 1993, s. 36-37.

12 Tamże, s. 44.

13 Tamże, s. 49. 
tycznie, ale jednak, stwierdzić, że obraz zmultiplikowany, cyfrowy i niematerialny nie musi być słaby, a wręcz może okazać się potężny.

Odcieleśnieniu obrazu uwagę poświęcało wielu badaczy, z tych współczesnych wymienić warto choćby Mitchella czy Bruno Latoura. Ten pierwszy, nawiązując do dychotomii obecności i nieobecności, zauważa:

Nie ma [...] szansy na wymknięcie się dialektyce życia i śmierci, pragnienia i agresji, w zgodzie z zasadniczą ontologią obrazów. [...] Wieczne wahanie się obrazu pomiędzy obecnością a nieobecnością [...] jest jego konstytutywną właściwościąi14.

Przechodząc do interesujących nas tutaj kwestii, odniosę się do koncepcji Marka Kaźmierczaka wyłożonej w niezwykle interesującej pracy Auschwitz $w$ Internecie. Przedstawienia Holokaustu w kulturze popularnej. Co oczywiste, rzecz ta dotyczy obecności obrazu Auschwitz w przestrzeni wirtualnej, ale zawiera także niemało refleksji o charakterze teoretycznym, które można ekstrapolować na ogół zagadnień związanych z wizualną reprezentacją innych istotnych treści. Autor rozpoczyna swoje rozważania od uwagi, że fizyczne miejsce, jakim jest Auschwitz, "nie jest tożsame z miejscem w globalnej sieci. Internet nie funkcjonuje w komunikacyjnej, semiotycznej, kulturowej ani medialnej próżni, lecz w różnorodny sposób łączy to, co wirtualne, z tym, co rzeczywiste"15. Kaźmierczak zwraca przy tym uwagę na konieczność badania zarówno oficjalnych dyskursów (np. instytucjonalnych czy muzeów), jak i nieoficjalnych (w znacznej mierze niefunkcjonujących poza cyberprzestrzenią) ${ }^{16}$. Jest to dla nas interesujące o tyle, że uświadamia nam, że oto można objąć zakresem przedmiotu badań z jednej strony te fenomeny, które istnieją jednocześnie $\mathrm{w}$ rzeczywistości, jak i w przestrzeni wirtualnej, oraz, z drugiej strony, te, których środowiskiem jest wyłącznie Internet. „Jest to konieczne - pisze Kaźmierczak, odnosząc się do koncepcji konwergencji Henry'ego Jenkinsa - gdyż sieć jest medium, w którym funkcjonują konwergentne technologie tworzenia i przekazywania tekstów wykorzystujące audiowizualne kody komunikacji"17. Zatrzymując się przy pierwszym z wymienionych rodzajów dyskursów, a więc przy tym oficjalnym, warto zwrócić uwagę na interesujący problem „przedstawienia realnego miejsca $\mathrm{w}$ wirtualnym (inter)miejscu [...], miejsca [...] oderwanego od fizycznej przestrzeni”. „Internet - pisze Kaźmierczak - jest swoistym nie-miejscem,

14 W.J.T. Mitchell, Czego pragna obrazy..., dz. cyt., s. 96-97.

${ }_{15}$ M. Kaźmierczak, Auschwitz w Internecie. Przedstawienia Holokaustu w kulturze popularnej, Poznań 2012, s. 8.

16 Tamże, s. 9-10

17 Tamże, s. 11. 
czyli przestrzenią pozbawioną niepowtarzalnych cech miejsca, nieposiadającą własnej historii i tożsamości, ale za to umożliwiającą powtórne zaistnienie «gdzie indziej» różnym przekazom"18. I tak na przykład - by ograniczyć się tylko do polskich stron - możemy w sieci niemal zwiedzić Dom Edyty Stein (http://www.domedytystein.pl/), obejrzeć zdjęcia miejsc z nią związanych (http://www.edytastein.org.pl/pl/4-edyta-stein/3-dom-edyty-stein/), czy zapoznać się z wnętrzem Muzeum Edyty Stein w Lublińcu (http:// lubliniec. $\mathrm{pl} /$ muzeum-edyty-stein). Są to wszystko miejsca istniejące w rzeczywistości, poza siecią, ale także dostępne użytkownikowi za pośrednictwem Internetu. Treści te, przekazy wizualne i rozmaite wizualne reprezentacje istnieją niejako w dwóch przestrzeniach, ich obecność jest zwielokrotniona. Przedstawienia w cyberprzestrzeni są znakowe oraz utrwalone w przekazach tekstualnych, dlatego mogą być przetwarzane w technologii naśladowczej ${ }^{19}$.

Innym wartym wspomnienia aspektem jest obecność w Internecie "tekstów kultury, które pojawiły się w innych mediach" 20 . Tak funkcjonują w sieci okładki i rozdziały książek Stein lub jej poświęconych, fragmenty filmów powstałych na jej temat czy ilustracje do artykułów prasowych. Kaźmierczak, za Zbigniewem Klochem, zauważa, że "teksty kultury mają wymiar materialny, w postaci konkretnych przekazów dostępnych w Internecie, oraz «duchowy», [zgodnie z którym] utrwalone w postaci cyfrowej przekazy mają zdolność do bycia medium różnych idei, wartości, treści kształtujących postawy czy oddziałujących na kompetencje użytkowników" 21.

\section{Obrazki, ikony, gadżety: Edyta Stein w Internecie}

Kontynuując tak rozpoczęte rozważania, dokonam przeglądu wizerunków Edyty Stein zapośredniczonych przez digitalną sieć. Przegląd ten, rzecz jasna, nie jest wyczerpujący ani kompletny, ma stanowić raczej swoisty rekonesans, wstępne rozeznanie. Najczęściej pojawiającym się wizerunkiem Stein towarzyszącym stronom jej poświęconym są dwa znane portrety: 1) w kapeluszu: osoby świeckiej, Żydówki, 2) karmelitanki w zakonnym habicie. Ale Internet pełen jest rozmaitych, mniej i bardziej kontrowersyjnych przedstawień Świętej.

\footnotetext{
18 Tamże, s. 19.

19 Tamże, s. 23.

20 Tamże, s. 127.

21 Tamże.
} 


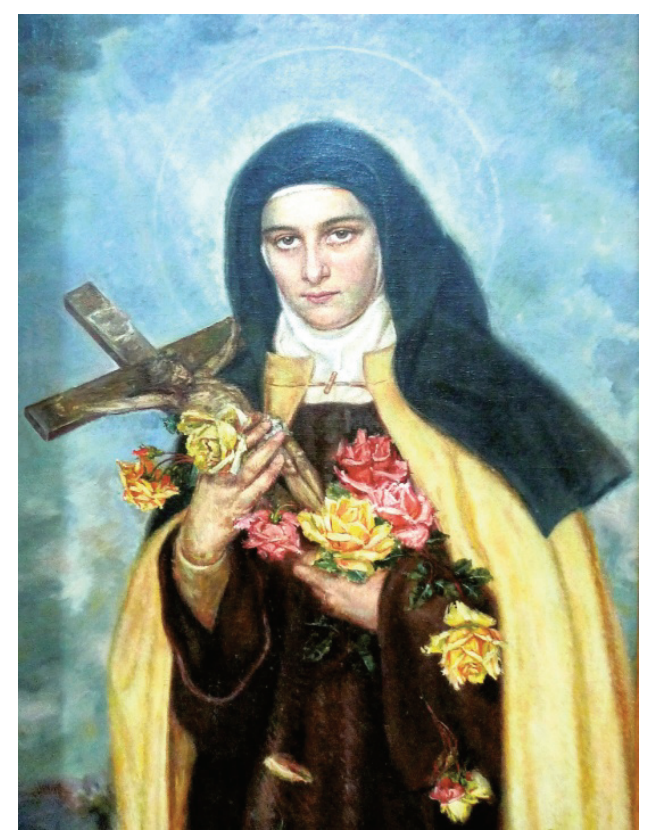

Rys. 1: Twarz św. Edyty Stein wpisana w postać św. Teresy z Lisieux, Święta filozofka, Gazeta Wyborcza, dodatek Ale Historia, lipiec 2012, URL: http:/ / wyborcza.pl/alehistoria/1,127747,12202330,Swieta_filozofka.html [dostęp: 10.11.2013]

Odniosę się do obrazu, jakim został zilustrowany wywiad z prof. Anną Grzegorczyk w dodatku prasowym Ale Historia. Niekompetentny odbiorca nie dostrzeże nic niezwykłego w tym przedstawieniu świętej. Mamy oto zakonnicę $\mathrm{w}$ habicie - klasyczna reprezentacja, niebudząca zastrzeżeń. Jednak uważniejszy i przede wszystkim bardziej kompetentny odbiorca tego przekazu szybko zauważy, że mamy tu do czynienia ze swoistym intertekstem, tekstem $\mathrm{w}$ tekście, złożeniem jednego wizerunku z dwóch. Oto w postać św. Teresy z Lisieux „wpisana” została twarz św. Teresy Benedykty od Krzyża. Ten niespotykany kolaż staje się niezwykle wdzięcznym przedmiotem semiotycznych analiz, które czynić można, odnosząc się na przykład do Jurija Łotmana koncepcji semiosfery, dodając do tego pojęcia epitet: digitalna. Nie sposób bowiem zaprzeczyć, że żyjemy współcześnie w cyfrowej przestrzeni znakowej, która stanowi znakomite środowisko dla swobodnego łączenia danych, kompilowania obiektów, „miksowania” obrazów. W omawianym przypadku mamy przedstawioną sylwetkę św. Teresy z Lisieux, której atrybutami w ikonografii chrześcijańskiej są róże, natomiast twarz, jej rysy, przynależą już do Edyty Stein. 
Edyta Stein bardzo często przedstawiana jest z elementami krajobrazu, które jednoznacznie odnoszą odbiorcę do miejsca, jakim jest obóz koncentracyjny (np. druty kolczaste) czy nawet konkretnie: Auschwitz (charakterystyczna panorama w tle obrazu, tory). Eco nazwałby te charakterystyczne przedstawienia "sematami ikonicznymi”, na których poziomie najczęściej zatrzymuje się kod ikoniczny22. Wskazane "atrybuty": druty kolczaste, tory, elementy architektury obozu, stanowią swoisty semat ikoniczny, którego kody zawierają ściśle denotujące elementy relewantne - takie, które pozwalają od razu rozpoznać to, co przedstawione. Często Stein jest na nich dodatkowo „charakteryzowana” jakimiś typowymi, na przykład dla swojego pochodzenia, przedmiotami (menora, Gwiazda Dawida) - taki zabieg „zakotwicza" 23 przekaz, redukuje konotacje. Oto przykłady takich obrazów istniejących w Internecie.

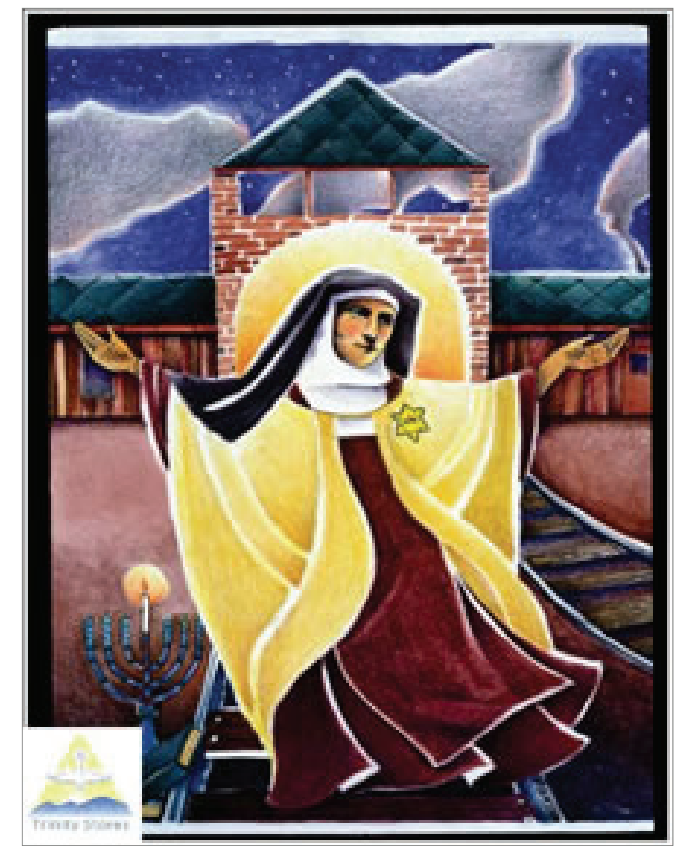

Rys. 2: Fotografia z bloga internetowego STA - The Roman Catholic Community of Saint Thomas Aquinas \& Holy Family,

URL: http:/ / stthomasaquinaschurch.blogspot.com/2007/08/st-edith-stein-pray-forus.html [dostęp: 10.11.2013]

22 Por. U. Eco, Nieobecna struktura, dz. cyt., zwłaszcza s. 125-136 i 155-158.

${ }^{23}$ Określenie R. Barthesa, por. tenże, Retoryka obrazu, dz. cyt. 


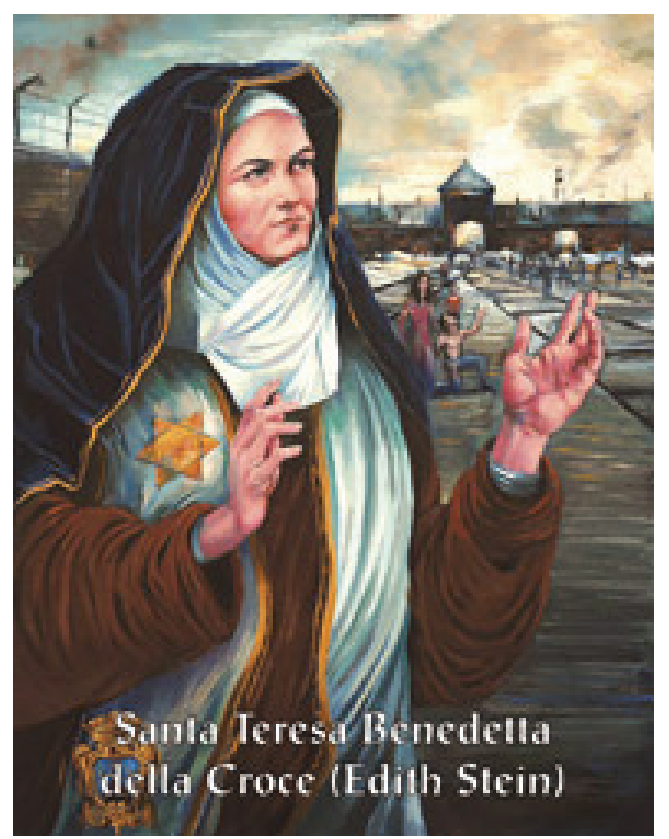

Rys 3: Fotografia ze strony internetowej Wspólnoty Cenacolo (Wieczernik), URL: http:/ / www.comunitacenacolo.it/viewpagina.asp?keypagina=4444 [dostęp: 10.11.2013]

Zupełnie osobną kategorię stanowią ikony Edyty Stein. Przywołajmy tu najważniejsze ustalenia Borysa Uspienskiego z jego semiotycznej lektury ikony. Dla rzetelności wywodu trzeba odnotować, że Uspienski koncentruje się na rosyjskim malarstwie ikon, jednakże można jego koncepcję ekstrapolować na inne obszary ikonopisarstwa. Jest ona zresztą w pewnym stopniu zbliżona do jakościowej metody znanej z metodologii materiałów wizualnych jako analiza kompozycji. Otóż w owym rosyjskim malarstwie ikon autor zauważa charakterystyczne dla malarstwa staroruskiego zniekształcenia rzeczywistych form przedstawionych przedmiotów: deformacje, przekształcenia, odwróconą perspektywę, zrównanie wymiarów, etc. Zniekształcenia te, precyzuje Uspienski, dotyczą $\mathrm{w}$ równym stopniu wszystkich postaci obrazu, a stopień podatności na pewne odchylenia perspektywy określony jest przez semantykę przedstawionej postaci. $W$ dawnym malarstwie ikon zawarte są dwa umowne systemy przekazu: (a) czysto geometryczny (geometryczne prawidłowości odchyleń perspektywy) oraz (b) semantyczny. Ważniejsze semantycznie postacie i linie $\mathrm{w}$ obrazie zwykle znajdują się na pierwszym planie, mniej ważne tworzą tło. Semantycznie ważne są na przykład figury przedstawiające ludzi, świętych, aniołów itp., mniej ważne są na przykład otaczające ich przedmioty. "Charakterystyczne jest - czytamy dalej - że fi- 
gury semantycznie ważne $\mathrm{w}$ mniejszym stopniu podlegają deformacji perspektywicznej, podczas gdy deformacja tła jest największa i następuje prawie automatycznie. Jednocześnie figury najbardziej znaczące są podporządkowane szczególnym prawidłowościom semantycznym, również dosyć umownym"24. Dla przykładu, piszący księgę (ku widzowi zwrócony jest nie tylko sam piszący księgę, ale również sama księga), patrzący na ikonę, stojący, klęczący itd. przed nią zwracają się ku oglądającemu ikonę, a wszystko to jest uzasadnione semantycznie. Innym przykładem takich zniekształceń jest, wedle Uspienskiego, kwestia budynku znajdującego się w tle - akcja przedstawiona na ikonie tak naprawdę dzieje się wewnątrz niego, tymczasem jest on przedstawiony z zewnątrz. Zabieg taki służy rekonstrukcji rzeczywistego stosunku budynku do figur i figur do budynku. Kompozycja semantyczna zatem warunkuje frontalny układ obrazu, a podporządkowane jej są głównie figury ludzi, aniołów, świętych, etc. - a więc wszystkich postaci ważniejszych semantycznie - oraz przedmioty nieożywione (frontalnie zwrócone do widza budynki, księgi, ikony), a także szczególnie ważne linie (np. linia stołu).

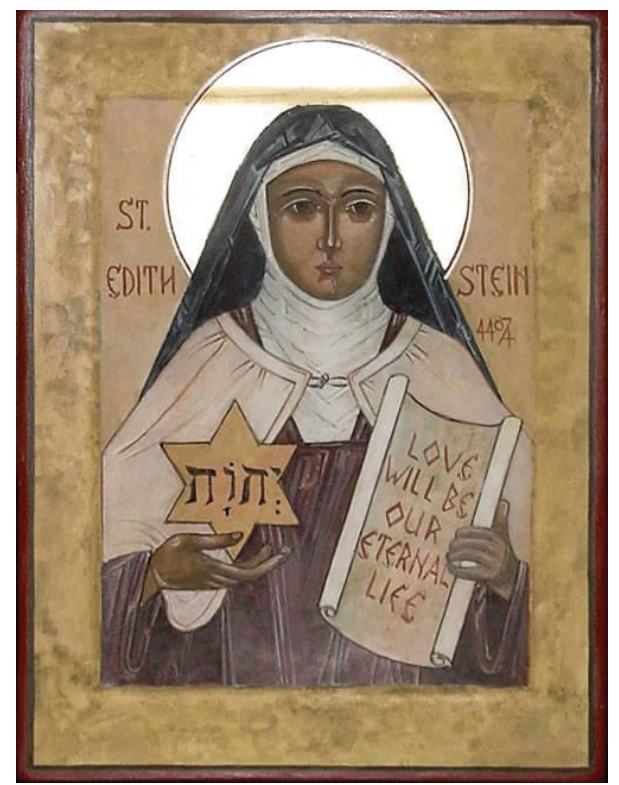

Rys. 4: Ikona św. Edyty Stein, blog internetowy Communio,

URL: http:/ / communio.stblogs.org/wp-content/uploads/2013/08/Edith-Stein-icon.jpg [dostęp: 10.11.2013]

24 B. Uspienski, O systemie przekazu obrazu w rosyjskim malarstwie ikon, tłum. Z. Zaron, w: Semiotyka kultury, red. E. Janus, M.R. Mayenowa, Warszawa 1977, s. 332 i n. 
Św. Teresa Benedykta od Krzyża przedstawiana jest na ikonach z chrześcijańskim krzyżem bądź z Gwiazdą Dawida jako atrybutami symbolizującymi jej przynależność narodową i wyznaniową (a także szczególny stosunek do krzyża). Jeśli przedstawiona jest $\mathrm{z}$ księgą, to jest ona otwarta w stronę obcującego z ikoną. Jej postać, jako ważna semantycznie, jest wyeksponowana, podlegająca regule frontalności.

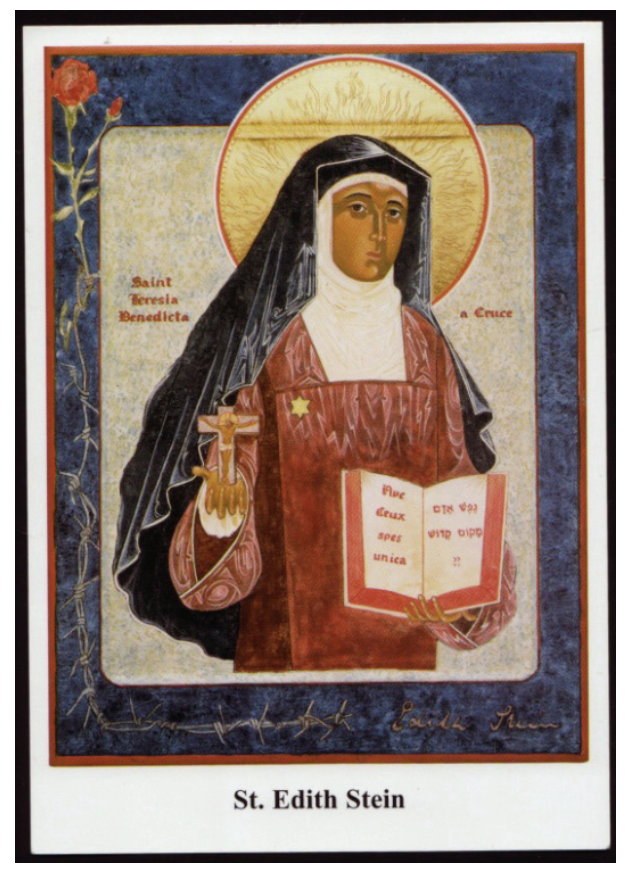

Rys. 5: Ikona św. Edyty Stein, blog Carmelite Heritage,

URL: http:/ / carmeliteheritage.blogspot.com/ [dostęp: 10.11.2013]

\section{Dwa oblicza współczesnego ikonoklazmu}

Odniosę się do uwag poczynionych w ramach wykładu Wspótczesny ikonoklazm ${ }^{25}$ przez ks. prof. Jerzego Tofiluka, rektora Prawosławnego Seminarium Duchownego w Warszawie. Obecnie ikony czczone są jako odwołanie do praobrazu, stanowią one uobecnienie Chrystusa lub tego świętego, który jest na nich przedstawiony. Z uwagi na wcześniej poczynio-

${ }^{25}$ J. Tofiluk, Wspótczesny ikonoklazm. Wykład wygłoszony w Poznaniu 22 października 2009 w ramach IV Poznańskich Dni Kultury Prawosławnej „Ikona”, organizowanych przez Fundację Barak Kultury. 
ne refleksje na temat konsekracji obrazu, interesująca jest także kwestia świętości ikony i jej źródeł. Otóż, jak zauważył ks. prof. Tofiluk, jest ona święta, ponieważ w ikonie jest obraz Boga, a nie dlatego, że została poświęcona przez osobę duchowną. A zatem, ponownie, sam akt konsekracji nie czyni obrazu świętym i nie przydaje mu znaczeń, ponieważ on sam jest już taki „źródłowo”. Współczesnym ikonoklazmem, rozumianym jako nadużycie wobec obrazu, są, wedle Tofiluka, wszelkie dewocjonalia, kalendarze, filiżanki czy nawet wino cerkiewne z ikoną Chrystusa - to wszystko jest odmówieniem świętości ikonie, wyrazem jej spowszednienia. Można więc rzec, że dziś ikonoklazm to nie tyle kontestowanie obrazu, co nadużycia względem niego, powielanie go i sytuowanie w niewłaściwym kontekście, a także fakt nierozumienia ikony $\mathrm{i}$ jej istoty.

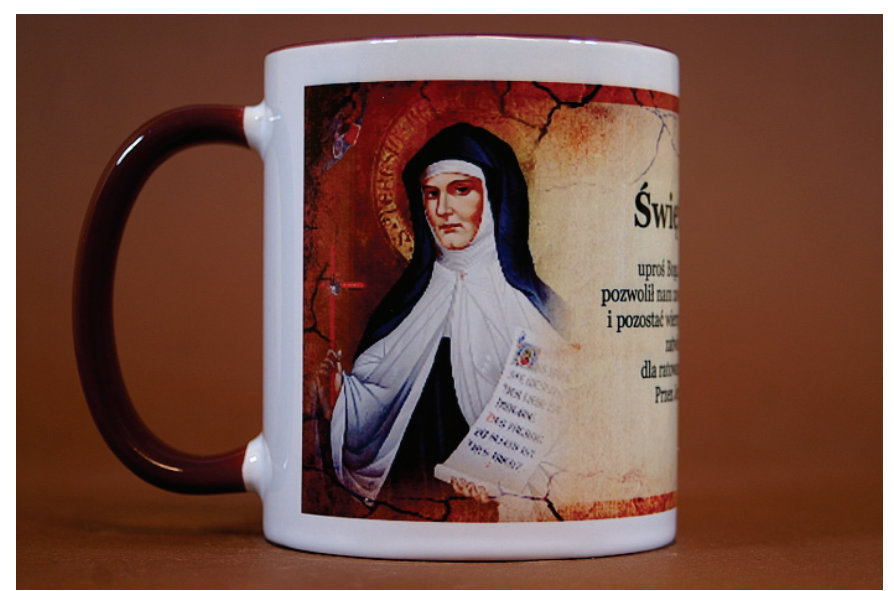

Rys. 6: Kubek - gadżet z wizerunkiem św. E. Stein, sklep internetowy Dystrybucja katolicka.pl, URL: http://www.dystrybucjakatolicka.pl/kubek-sw9/kubki [dostęp: 10.11.2013]

Wracając na koniec do myśli Baudrillarda, odnieśmy się do jego koncepcji obrazu zwielokrotnionego, którą omawia on na przykładzie twórczości artystycznej Andy'ego Warhola: „Tym, co u Warhola od razu ujęło Baudrillarda - pisze w Przedmowie do Spisku sztuki Sylvère Lotringer - była nie sama postać wielkiego artysty, lecz maszyneria, za pomocą której z wielką wirtuozerią udało mu się samego siebie przeobrazić. [...] Andy'emu Warholowi udało się [...] zastąpić sztukę mechaniczną reprodukcją, co odsyłało zarazem banalność ku jej nieprzekraczalnej zagadkowości"26. Nieograniczona

${ }^{26}$ J. Baudrillard, Spisek sztuki. Iluzje i deziluzje estetyczne z dodatkiem wywiadów o "Spisku sztuki", tłum. S. Królak, Warszawa 2006, s. 30-34. 
reprodukowalność, co warto dodać, jest rezultatem oderwania się znaków od rzeczywistości i istnienia czystych symulakrów, multiplikowanych i powtarzalnych w sposób niczym nieograniczony.

Andy Warhol - pisze Baudrillard - wychodzi od dowolnego obrazu, by wypreparować z niego wyobrażenie i uczynić z niego czysty produkt wizualny, czystą logikę, nieuwarunkowany symulakr. [...] Nie jest to już zatem jakakolwiek transcendencja, lecz spotęgowanie znaku, który tracąc wszelkie naturalne znaczenie, promienieje w pustce sztucznym blaskiem. Warhol jako pierwszy wprowadza nas w obręb fetyszyzmu ${ }^{27}$.

Warhol dokonał „spotęgowania przedmiotu, znaku, obrazu, symulakru, wartości [...], przesunął estetykę aż po jej krańce, tam, gdzie pozbawiona jest już jakości estetycznej i ulega odwróceniu, zyskując przeciwne znaczenie" 28 . To zjawisko zostaje z kolei przez Baudrillarda nazwane współczesnym ikonoklazmem: nie polega on na fizycznym niszczeniu materialnie istniejących przedstawień wizualnych, jakie znany z historii kultury, lecz na ich niszczeniu poprzez nieskończone kopiowanie, multiplikowanie i rozpowszechnianie, a to wszystko - dodajmy - wywołane zostało przejściem od obrazu analogowego do cyfrowego.

Przykładem takiego zwielokrotnienia wizerunku Edyty Stein jest poniższa fotografia zmontowana na wzór Warholowskiej Liz Taylor i Marylin Monroe.

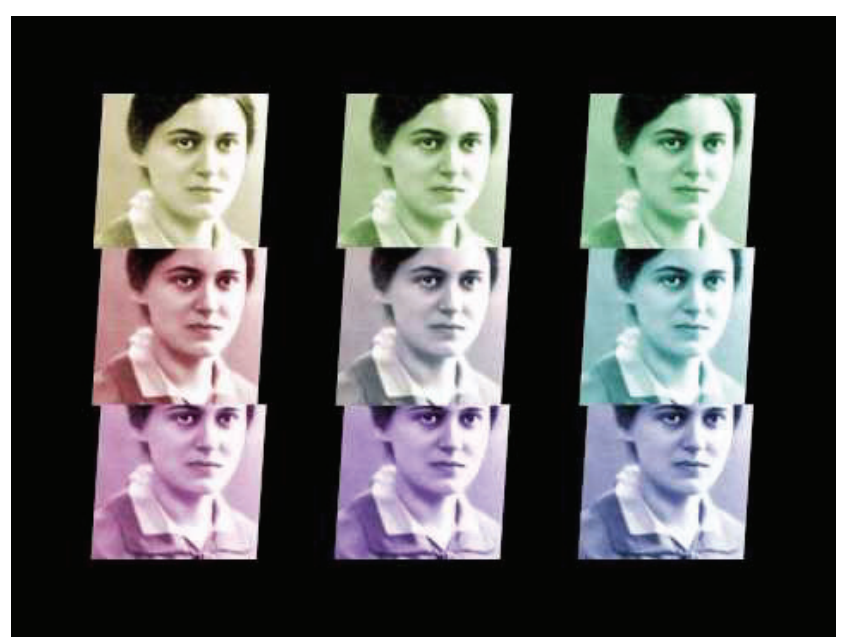

Rys. 7: Zmultiplikowany wizerunek Świętej,

URL: http:/ /i.ytimg.com/vi/3_ZrW5sR3WA/0.jpg [dostęp: 10.11.2013]

27 Tamże, s. 63-65.

28 Tamże, s. 88-92. 
Podobny zabieg zresztą - z wykorzystaniem wizerunku wspomnianej już w tym artykule św. Teresy z Lisieux - zastosowano w nadruku na torbie - gadżecie.

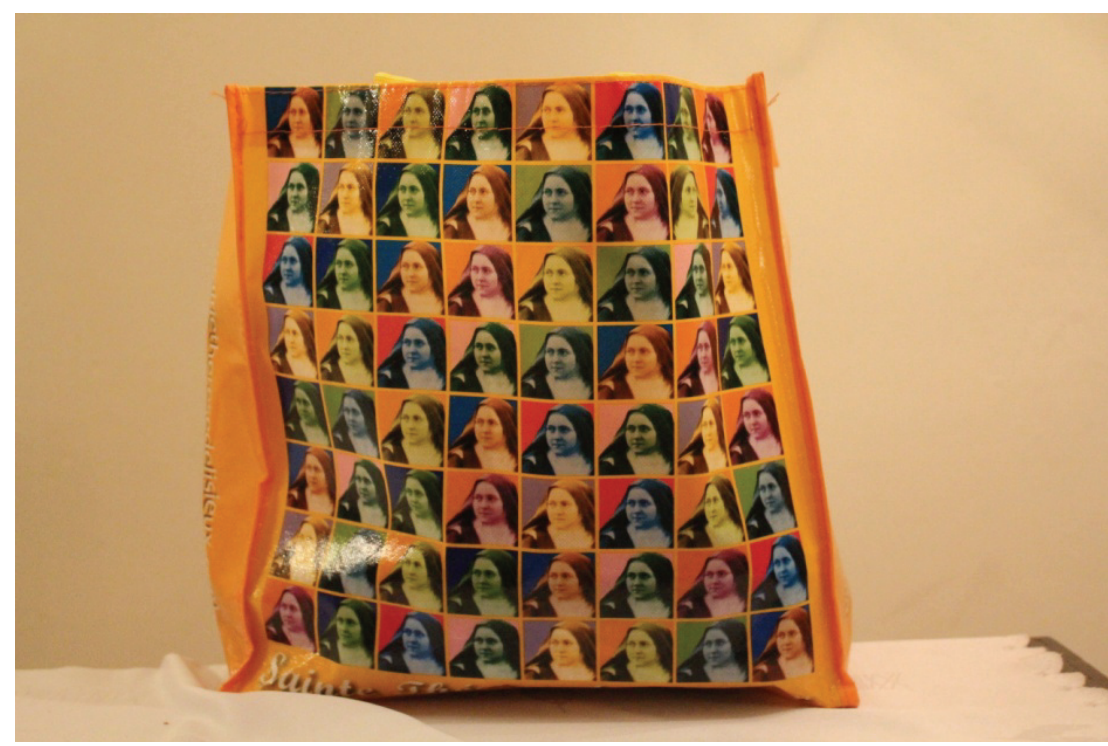

Rys. 8: Zmultiplikowany wizerunek św. Teresy z Lisieux, torba z adresem producenta: www.librairietheresedelisieux.com (fot. K.M.)

Ten siłą rzeczy ograniczony i arbitralny wybór wizerunków Edyty Stein dostępnych jedynie w Internecie bądź przez Internet zapośredniczonych z fizycznie istniejącej rzeczywistości uzmysławia nam, jak rozmaite i dalekie od kanonu mogą być przedstawienia i wizerunki świętych. Niektóre z nich są jedynie obrazami, idolami i czystymi wizualnościami, inne noszą znamiona symbolu, uobecniają przedstawioną na obrazie postać. Szczegółowa analiza poszczególnych reprezentacji nie jest tu możliwa, wymaga bowiem osobnych studiów i późniejszej obszernej publikacji wyników badań. Co jednak istotne, sądzę, że wnioski, do jakich doprowadziły powyższe rozważania, ująć można w dwie duże grupy: (1) metody semiotyczne (bo przedstawiono tu kilka) są badawczo efektywne i dostarczają użytecznych narzędzi analitycznych, (2) wizerunek cyfrowo zapośredniczony, odcieleśniony czy zdematerializowany, może być potężny, działać i wywierać wpływ na jego odbiorcę. 


\section{The Power or Impotence of the Image? \\ Toward the Semiotic Analysis of Edith Stein's Representations in Cyberspace}

\section{Summary}

The author poses several questions: is it possible for the saint to have a digital image? Can we analyse the presence of the saint in cyberspace and is a semiotic view in this field possible? The main aim of the article is to indicate some of visual semiotic concepts, including those referring to digital images, and applying them to selected representations of Edith Stein found on the Internet.

Firstly, the author tries to recognise differences between concepts and notions connected to visuality (for example picture, image and representation). In the next part, there is a passage dedicated to the concepts of presence and non-presence, action and signification of an image on the Internet. In the main part of the text the author describes and analyses selected images of Edith Stein found in cyberspace using a semiotic approach. The last passage contains a presentation of two different iconoclasm's concepts: the theological and the poststructural. 